Article

\title{
Effect of Temperature on the Structural and Physicochemical Properties of Biochar with Apple Tree Branches as Feedstock Material
}

\author{
Shi-Xiang Zhao, Na Ta and Xu-Dong Wang * \\ College of Resources \& Environment, Northwest A\&F University, 3 Taicheng Road, Yangling 712100, China; \\ zhaoshixiang1989@126.com (S.-X.Z.); tana0214@163.com (N.T.) \\ * Correspondence: wangxd@nwsuaf.edu.cn; Tel./Fax: +86-29-8708-0055
}

Received: 18 April 2017; Accepted: 21 August 2017; Published: 30 August 2017

\begin{abstract}
The objective of this study was to study the structure and physicochemical properties of biochar derived from apple tree branches (ATBs), whose valorization is crucial for the sustainable development of the apple industry. ATBs were collected from apple orchards located on the Weibei upland of the Loess Plateau and pyrolyzed at 300, 400, 500 and $600{ }^{\circ} \mathrm{C}$ (BC300, BC400, BC500 and $\mathrm{BC} 600)$, respectively. Different analytical techniques were used for the characterization of the different biochars. In particular, proximate and element analyses were performed. Furthermore, the morphological, and textural properties were investigated using scanning electron microscopy (SEM), Fourier-transform infrared (FTIR) spectroscopy, Boehm titration and nitrogen manometry. In addition, the thermal stability of biochars was also studied by thermogravimetric analysis. The results indicated that the increasing temperature increased the content of fixed carbon $(C)$, the $C$ content and inorganic minerals $(\mathrm{K}, \mathrm{P}, \mathrm{Fe}, \mathrm{Zn}, \mathrm{Ca}, \mathrm{Mg})$, while the yield, the content of volatile matter (VM), $\mathrm{O}$ and $\mathrm{H}$, cation exchange capacity, and the ratios of $\mathrm{O} / \mathrm{C}$ and $\mathrm{H} / \mathrm{C}$ decreased. Comparison between the different samples show that highest $\mathrm{pH}$ and ash content were observed in $\mathrm{BC} 500$. The number of acidic functional groups decreased as a function of pyrolysis temperature, especially for the carboxylic functional groups. In contrast, a reverse trend was found for the basic functional groups. At a higher temperature, the brunauer-emmett-teller (BET) surface area and pore volume are higher mostly due to the increase of the micropore surface area and micropore volume. In addition, the thermal stability of biochars also increased with the increasing temperature. Hence, pyrolysis temperature has a strong effect on biochar properties, and therefore biochars can be produced by changing pyrolysis temperature in order to better meet their applications.
\end{abstract}

Keywords: biochar; pyrolysis temperature; apple tree branch; physicochemical properties; structural

\section{Introduction}

Biochar is a carbon (C)-rich byproduct produced in an oxygen-limited environment [1], which has been gaining increasing attention over the last decade due to its potential to mitigate global climate change $[2,3]$. Biochar can be used not only as a soil amendment with the aim of improving soil physical, chemical and biological properties [4,5], but also as an adsorbent to remove organic and inorganic pollutants [6,7]. The functions and applications of biochars mostly depend on their structural and physicochemical properties [8], therefore, it is very important to characterize the structural and physicochemical properties of biochar before its use.

Various types of biomass (wood materials, agricultural residues, dairy manure, sewage sludge, et al.) have been used to produce biochars under different pyrolysis conditions $[9,10]$. During pyrolysis, biomass undergoes a variety of physical, chemical and molecular changes [11]. Previous studies indicated that pyrolysis condition and feedstock type significantly affect the structural 
and physicochemical characteristics of the resulting biochar products [12-14]. Generally, woody biomass provides a more C-rich biochar compared to other feedstocks since it contains varying amounts of hemicellulose, cellulose, lignin and small quantities of other organic extractives and inorganic compounds [15]. $\mathrm{Xu}$ and Chen [16] suggest that higher lignin and minerals content result in a higher yield of biochar. Therefore, woody biomass is one of the most important sources for biochar production.

The structural and physicochemical properties of biochar, such as surface area, pore structures, surface functional groups and element composition, can also be influenced by varying the pyrolysis condition, such as pyrolysis temperature, heating rate and holding time $[17,18]$. The pyrolysis temperature is reported to significantly influence the final structural and physicochemical properties of biochar due to the release of volatiles as well as the formation and volatilisation of intermediate melts [18]. Previous studies indicated that higher temperature resulted in a higher $C$ content, while the losses of nitrogen $(\mathrm{N})$, hydrogen $(\mathrm{H})$ and oxygen $(\mathrm{O})$ were also recorded [19]. In addition, increasing the temperature lead to an increase the ash and fixed $\mathrm{C}$ contents, and to a decrease the content of volatile materials [20]. Furthermore, the increase in pyrolysis temperature affects $\mathrm{H} / \mathrm{C}$ and $\mathrm{O} / \mathrm{C}$ ratios; porosity; surface area; surface functional groups and cation exchange capacity (CEC) and so on [21]. In particular, biochar produced at high temperature has high aromatic content, which is recalcitrant to decomposition [22]. In contrast, biochar produced at low temperature has a less-condensed C structure and, therefore, may improve the fertility of soils [23]. Therefore, the pyrolysis temperature was investigated in this study.

Weibei upland of the Loess Plateau has been recognized as one of the best apple production areas in the world due to its special topography and climate features which are suitable for planting apples [24]. Apple tree branches (ATBs) are a major agricultural residue in this region due to the quick development of the apple-planted area in recent years. During the autumn of each year, the residues might be burned by the fruit grower with the aim of reducing the occurrence of plant diseases and insect pests, which then becomes an important source of atmospheric $\mathrm{CO}_{2}$. Thus, conversion of ATBs into biochar has the potential to be used to mitigate environmental problems. In addition, the biochar products also can be used as a soil amendment, which can improve the soil quality $[25,26]$. Therefore, the aim of this study was to examine the structure and physicochemical properties of biochar produced at different pyrolysis temperatures using ATB as feedstock. Such understanding is crucial for the sustainable development of apple industry on the Weibei upland.

\section{Materials and Methods}

\subsection{Feedstock Preparation}

ATBs were collected from apple orchards located on the Weibei upland of the Loess Plateau, Northwest China ( $34^{\circ} 53^{\prime} \mathrm{N}, 108^{\circ} 52^{\prime}$ E). Prior to the experiments, ATBs were ground to a particle size of less than $2 \mathrm{~mm}$ and then washed with deionized water several times to remove impurities. These pre-prepared samples were dried at $80^{\circ} \mathrm{C}$ for $24 \mathrm{~h}$ to remove moisture.

\subsection{Biochar Production}

Pyrolysis experiments were carried out in a muffle furnace (Yamato Scientific Co., Ltd, FO410C, Tokyo, Japan) under nitrogen gas stream (at a rate $630 \mathrm{~cm}^{3} \cdot \mathrm{min}^{-1}$, standard temperature and pressure $298 \mathrm{~K}, 101.2 \mathrm{kPa}$ ). The feedstock was placed in a stainless steel reactor of $20.5 \mathrm{~cm}$ internal length, $12.2 \mathrm{~cm}$ internal width and $7.5 \mathrm{~cm}$ internal height with a lid and subjected to pyrolysis at different temperatures $\left(300,400,500\right.$ and $600{ }^{\circ} \mathrm{C}$, respectively) for $2 \mathrm{~h} 10 \mathrm{~min}$. The pyrolysis heating rate employed was $10^{\circ} \mathrm{C} \mathrm{min}^{-1}$. After pyrolysis, the reactor was left inside the furnace to cool to room temperature. The biochars obtained were labeled as BC300, BC400, BC500 and BC600, respectively. 
All biochars were weighed and then the generated biochars were milled to pass through a $0.25 \mathrm{~mm}$ sieve (60 mesh) for further analysis and use. The yield of biochar was calculated as follows:

$$
\text { Yield }(\%)=\frac{\text { mass of biochar }(g)}{\text { oven dry mass of feedstock }(g)} \times 100 \%
$$

\subsection{Characterization of Biochar}

\subsubsection{Proximate Analysis, $\mathrm{pH}$ and Cation Exchange Capacity}

The contents of volatile matter (VM) and ash were determined using the American Society for Testing and Materials (ASTM) D5142 method [27]. VM content was determined as weight loss after heating the char in a covered crucible to $950{ }^{\circ} \mathrm{C}$ and holding for $7 \mathrm{~min}$. Ash content was determined as weight loss after combustion at $750^{\circ} \mathrm{C}$ for $6 \mathrm{~h}$ with no ceramic cap. Fixed $\mathrm{C}$ content was calculated by the following equation:

$$
\text { Fixed carbon } \%=100 \%-(\text { Ash } \%+\text { Volatile matter } \%)
$$

The $\mathrm{pH}$ of biochars was measured using a $\mathrm{pH}$ meter at a 1:5 solid/water ratio after shaking for $30 \mathrm{~min}$. The CEC of biochar was estimated using an $\mathrm{NH}_{4}{ }^{+}$replacement method [28]. Briefly, $0.20 \mathrm{~g}$ was leached five times with $20 \mathrm{~mL}$ of deionized water. Then, the biochar was leached with $20 \mathrm{~mL}$ of $1 \mathrm{~mol} \cdot \mathrm{L}^{-1} \mathrm{Na}$-acetate ( $\mathrm{pH} 7$ ) five times. The biochar samples were then washed with $20 \mathrm{~mL}$ of ethanol five times to remove the excess $\mathrm{Na}^{+}$. Afterwards, the $\mathrm{Na}^{+}$on the exchangeable sites of the biochar was displaced by $20 \mathrm{~mL}$ of $1 \mathrm{~mol} \cdot \mathrm{L}^{-1} \mathrm{NH}_{4}$-acetate ( $\mathrm{pH}$ 7) five times, and the CEC of the biochar was calculated from the $\mathrm{Na}^{+}$displaced by $\mathrm{NH}_{4}{ }^{+}$.

\subsubsection{Elemental and Nutrients Analysis}

A CHN Elemental Analyzer (Vario EL III, Heraeus, Germany) was used to determine the contents of $\mathrm{C}, \mathrm{N}$ and $\mathrm{H}$. The $\mathrm{O}$ content (\%) was calculated by the following equation: $\mathrm{O}(\%)=100-(\mathrm{C} \%+\mathrm{H} \%$ $+\mathrm{N} \%+\mathrm{Ash} \%)$. The $\mathrm{H} / \mathrm{C}$ and $\mathrm{O} / \mathrm{C}$ ratios were also calculated. Total nutrients $(\mathrm{K}, \mathrm{P}, \mathrm{Fe}, \mathrm{Mn}, \mathrm{Cu}, \mathrm{Zn}$, $\mathrm{Ca}$ and $\mathrm{Mg}$ ) in the biochar were extracted using a wet acid digestion method (concentration $\mathrm{HNO}_{3}+$ $30 \% \mathrm{H}_{2} \mathrm{O}_{2}$ ) [29]. The nutrients in the digestion solution were determined using an ICAP Q ICP-MS spectrometer (ThermoFisher, Waltham, MA, USA).

\subsubsection{Surface Properties of Biochars}

The surface morphology of these biochars was examined using an environmental scanning electron microscopy (SEM) system (JEOL JSM-6360LV, Tokyo, Japan). Biochars were held onto an adhesive carbon tape on an aluminum stub followed by sputter coating with gold prior to viewing. The surface area and porosity of biochars were measured using a NOVA 2200e analyser (Quantachrome Instruments, Boynton Beach, FL, USA) at liquid nitrogen temperature (77 K). The Brunauer-Emmett-Teller $(\mathrm{BET})$ surface area $\left(S_{\mathrm{BET}}\right)$, micropore surface area $\left(S_{\text {mic }}\right)$ and micropore volume $\left(V_{\text {mic }}\right)$, total pore volume $\left(V_{\mathrm{T}}\right)$ of the biochars produced at different temperatures were determined using the BET equation, t-plot method and single point adsorption total pore volume analysis, respectively [30]. Fourier-transform infrared (FTIR) spectra peaks of biochars were also obtained on pressed pellets of 1:10 biochar/KBr mixtures using a Tensor27 FTIR spectrometer (Bruker, Karlsruhe, Germany). The spectra were obtained at $4 \mathrm{~cm}^{-1}$ resolution from 400 to $4000 \mathrm{~cm}^{-1}$. The amount of acidic and basic functional groups was measured by the Boehm method [31].

\subsubsection{Thermal Stability Evaluation}

The thermal stability evaluation of the biochars was performed by thermogravimetric analysis (STA449F3, NETZSCH, Freistaat Bayern, Germany). Approximately $5 \mathrm{mg}$ of biochar was weighed into 
an alumina crucible, the sample was subjected to a thermogravimetric analysis in a nitrogen flow (gas flow of $50 \mathrm{~mL} \cdot \mathrm{min}^{-1}$ ) at a heating rate of $10^{\circ} \mathrm{C} \cdot \mathrm{min}^{-1}$, from $50^{\circ} \mathrm{C}$ to $1000{ }^{\circ} \mathrm{C}$.

\subsection{Statistical Analysis of Data}

All data were reported as means \pm standard deviation. The data were subjected to analysis of variance (ANOVA) using SAS version 8.0 (SAS Institute Inc, Cary, NC, USA). The least significant difference (LSD, $p<0.05)$ test was applied to assess the differences among the means.

\section{Results and Discussion}

\subsection{Effect of Temperature on the Basic Characteristics of Biochars}

\subsubsection{Proximate Analysis}

Table 1 presents the results of proximate analyses as a function of pyrolysis temperature. During the pyrolysis process, the temperature kept rising and was then held at the peak temperature for $2 \mathrm{~h}$ and $10 \mathrm{~min}$ before cooling down to room temperature. When the pyrolysis temperature increased from 300 to $500{ }^{\circ} \mathrm{C}$, the biochar yield sharply decreased from $47.94 \%$ to $31.71 \%$. This was probably due to most of the lignocellulosic material was decomposed at this temperature range [32]. While, when the pyrolysis temperature further increased from 500 to $600{ }^{\circ} \mathrm{C}$, the biochar yield only decreased from $31.71 \%$ to $28.48 \%$. This result indicated that most of the volatile fraction had been removed at lower temperatures.

Table 1. Proximate, elemental and nutrients analysis of biochars produced at different temperatures.

\begin{tabular}{|c|c|c|c|c|c|}
\hline \multicolumn{2}{|c|}{ Sample } & \multirow{5}{*}{$\begin{array}{c}\text { ВС300 } \\
47.94 \pm 1.27 \mathrm{a} \\
6.72 \pm 0.02 \mathrm{~d} \\
60.77 \pm 0.86 \mathrm{a} \\
32.50 \pm 0.86 \mathrm{~d}\end{array}$} & \multirow{5}{*}{$\begin{array}{c}\text { BC400 } \\
35.49 \pm 1.39 \mathrm{~b} \\
7.85 \pm 0.04 \mathrm{c} \\
29.85 \pm 0.90 \mathrm{~b} \\
62.30 \pm 0.93 \mathrm{c}\end{array}$} & \multirow{5}{*}{$\begin{array}{c}\text { BC500 } \\
31.73 \pm 1.02 \mathrm{c} \\
10.06 \pm 0.15 \mathrm{a} \\
23.19 \pm 0.34 \mathrm{c} \\
66.75 \pm 0.28 \mathrm{~b}\end{array}$} & \multirow{5}{*}{$\begin{array}{c}\text { BC600 } \\
28.48 \pm 0.72 \mathrm{~d} \\
9.40 \pm 0.21 \mathrm{~b} \\
14.86 \pm 0.63 \mathrm{~d} \\
75.73 \pm 0.76 \mathrm{a}\end{array}$} \\
\hline & Yeld (\%) & & & & \\
\hline Proximate & Ash (\%) & & & & \\
\hline analysis, dry & Volatile matter (\%) & & & & \\
\hline & Fixed carbon (\%) & & & & \\
\hline \multirow{4}{*}{$\begin{array}{l}\text { Elemental } \\
\text { analysis, dry } \\
\text { basis }\end{array}$} & C (\%) & $62.20 \pm 0.85 \mathrm{~d}$ & $71.13 \pm 2.39 c$ & $74.88 \pm 2.11 b$ & $80.01 \pm 4.58 \mathrm{a}$ \\
\hline & $\mathrm{H}(\%)$ & $5.18 \pm 0.19 a$ & $4.03 \pm 0.21 b$ & $2.88 \pm 0.08 c$ & $2.72 \pm 0.14 \mathrm{c}$ \\
\hline & N (\%) & $1.69 \pm 0.08 c$ & $1.94 \pm 0.06 \mathrm{a}$ & $1.77 \pm 0.08 \mathrm{~b}$ & $1.28 \pm 0.06 \mathrm{~d}$ \\
\hline & $\mathrm{O}(\%)$ & $24.21 \pm 0.62 \mathrm{a}$ & $15.05 \pm 2.35 b$ & $10.41 \pm 2.05 c$ & $6.59 \pm 1.38 c$ \\
\hline \multirow{8}{*}{$\begin{array}{l}\text { Nutrients } \\
\text { analysis, dry } \\
\text { basis }\end{array}$} & $\mathrm{K}(\%)$ & $0.57 \pm 0.01 \mathrm{c}$ & $0.89 \pm 0.03 b$ & $1.10 \pm 0.02 \mathrm{a}$ & $1.14 \pm 0.04 \mathrm{a}$ \\
\hline & $\mathrm{P}(\%)$ & $0.21 \pm 0.01 \mathrm{c}$ & $0.28 \pm 0.01 b$ & $0.34 \pm 0.01 \mathrm{a}$ & $0.34 \pm 0.01 \mathrm{a}$ \\
\hline & $\mathrm{Ca}\left(\mathrm{g} \cdot \mathrm{kg}^{-1}\right)$ & $12.90 \pm 0.46 \mathrm{~d}$ & $16.81 \pm 0.34 \mathrm{c}$ & $20.19 \pm 0.22 b$ & $20.89 \pm 0.48 \mathrm{a}$ \\
\hline & $\operatorname{Mg}\left(\mathrm{g} \cdot \mathrm{kg}^{-1}\right)$ & $3.01 \pm 0.06 \mathrm{~d}$ & $4.04 \pm 0.13 c$ & $4.69 \pm 0.10 \mathrm{~b}$ & $5.64 \pm 0.17 \mathrm{a}$ \\
\hline & $\mathrm{Fe}\left(\mathrm{mg} \cdot \mathrm{kg}^{-1}\right)$ & $268.35 \pm 6.53 \mathrm{~d}$ & $361.62 \pm 8.99 c$ & $480.52 \pm 10.58 b$ & $583.50 \pm 5.38 a$ \\
\hline & $\operatorname{Mn}\left(\mathrm{mg} \cdot \mathrm{kg}^{-1}\right)$ & $56.96 \pm 2.30 \mathrm{~d}$ & $79.26 \pm 0.28 c$ & $102.89 \pm 4.95 \mathrm{a}$ & $89.41 \pm 2.77 b$ \\
\hline & $\mathrm{Cu}\left(\mathrm{mg} \cdot \mathrm{kg}^{-1}\right)$ & $20.29 \pm 0.45 \mathrm{~d}$ & $50.53 \pm 1.96 c$ & $85.07 \pm 2.27 \mathrm{a}$ & $58.90 \pm 1.22 b$ \\
\hline & $\mathrm{Zn}\left(\mathrm{mg} \cdot \mathrm{kg}^{-1}\right)$ & $33.06 \pm 0.48 c$ & $53.30 \pm 1.41 b$ & $60.50 \pm 0.17 \mathrm{a}$ & $61.68 \pm 2.41 \mathrm{a}$ \\
\hline
\end{tabular}

Note: Values in the same row followed by the same letter are not significantly different at $p<0.05$ according to least significant difference test. All data were reported as means \pm standard deviation $(n=3)$. Fixed carbon was estimated by difference: Fixed carbon $\%=100 \%-($ Ash $\%+$ Volatile matter $\%)$. O content was estimated by difference: $\mathrm{O} \%=100 \%-(\mathrm{C} \%+\mathrm{H} \%+\mathrm{N} \%+\mathrm{Ash} \%)$.

The content of VM and fixed C for the generated biochars ranged from $14.86 \%$ to $60.77 \%$ and $33.60 \%$ to $73.50 \%$, respectively. An increase in the pyrolysis temperature decreased the content of VM, exhibiting a similar trend with the biochar yield, while an opposite trend was found for the content of fixed $C$. This might due to the fact that the increasing temperature resulted in the further crack of the volatiles fractions into low molecular weight liquids and gases instead of biochar [33]. Meanwhile, the dehydration of hydroxyl groups and thermal degradation of cellulose and lignin might also occurred with the increasing temperature [12]. These results confirmed that the increase in temperature enhanced the stability of biochar for the loss of volatile fractions [34]. It was interesting that the ash content remarkably increased from $6.72 \%$ to $10.06 \%$ with an increase in the pyrolysis temperature from 
300 to $500^{\circ} \mathrm{C}$. The increase in the content of ash resulted from progressive concentration of inorganic constituents [35], which also was confirmed by our nutrients analysis (Table 1). When pyrolysis temperature increased from 500 to $600{ }^{\circ} \mathrm{C}$, some inorganic materials might volatilize as gas or liquid, thus, the content of ash decreased at higher temperature $\left(600^{\circ} \mathrm{C}\right)$.

\subsubsection{Elemental and Nutrients Analysis}

The elemental composition for the generated biochars changed with pyrolysis temperature (Table 1). The $\mathrm{C}$ content increased from $62.20 \%$ to $80.01 \%$, while the $\mathrm{H}$ and $\mathrm{O}$ contents decreased from $5.18 \%$ to $2.72 \%$ and $24.21 \%$ to $6.59 \%$ as the pyrolysis temperature increased from 300 to $600{ }^{\circ} \mathrm{C}$, respectively. These results were consistent with previous results [36]. The decrease in the contents of $\mathrm{H}$ and $\mathrm{O}$ at higher temperature was likely due to the decomposition of the oxygenated bonds and release of low molecular weight byproducts containing $\mathrm{H}$ and $\mathrm{O}$ [15]. Interestingly, the highest $\mathrm{N}$ content was observed in BC400 (1.94\%). This was attributed to the incorporation of nitrogen into complex structures which were resistant to lower temperature and not easily volatilized [37]. Furthermore, the ratios of $\mathrm{H} / \mathrm{C}$ (the degree of aromaticity) [36] and $\mathrm{O} / \mathrm{C}$ (the degree of polarity) [38] varied as a function of pyrolysis temperature. In our study, the $\mathrm{H} / \mathrm{C}$ and $\mathrm{O} / \mathrm{C}$ ratios of biochars were significantly decreased from 1.00 to 0.41 and 0.29 to 0.06 with the increasing temperature, respectively (Figure 1 ). The gradually reduced in the $\mathrm{H} / \mathrm{C}$ and $\mathrm{O} / \mathrm{C}$ atomic ratios with the increasing pyrolysis temperature was mainly contributed to the dehydration reactions [39], which could be well described by the Van Krevelen diagram (Figure 1). In addition, the $\mathrm{H} / \mathrm{C}$ and $\mathrm{O} / \mathrm{C}$ ratios also indicated that the structural transformations [36] and surface hydrophilicity of biochar [40], the higher extent of carbonization and loss of functional groups containing $\mathrm{O}$ and $\mathrm{H}$ (such as hydroxyl, carboxyl, et al.) at higher temperature resulted in the lower ratios of $\mathrm{H} / \mathrm{C}$ and $\mathrm{O} / \mathrm{C}$, indicating that the surface of biochar was more aromatic and less hydrophilic [41,42].

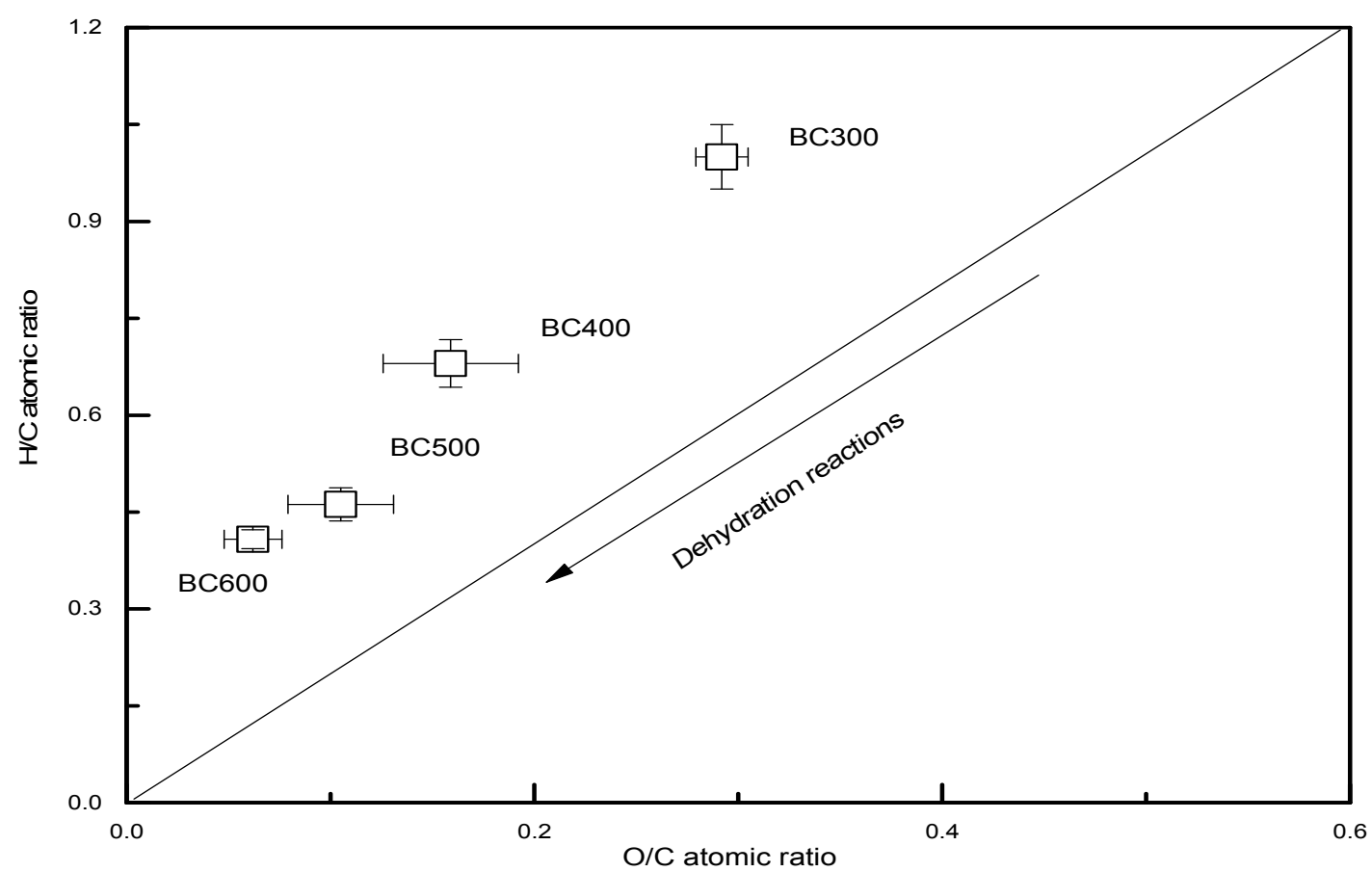

Figure 1. The van Krevelen plot of elemental ratios for biochars produced at different temperatures. Thick line represents the direction for dehydration reaction. Individual points are averages $(n=3)$ and error bars are standard deviations.

In addition, the nutrients $\mathrm{K}, \mathrm{P}, \mathrm{Ca}, \mathrm{Mg}, \mathrm{Fe}$ and $\mathrm{Zn}$ were also increased with increasing the pyrolysis temperature (Table 1). While, the highest concentration of $\mathrm{Cu}\left(85.07 \mathrm{mg} \cdot \mathrm{kg}^{-1}\right)$ and $\mathrm{Mn}$ 
(102.89 $\left.\mathrm{mg} \cdot \mathrm{kg}^{-1}\right)$ were found in BC500. Pituello et al. [43] suggested that some metals might volatilize at high temperature. Sun et al. also found a decrease in the concentration of $\mathrm{Ca}$ and $\mathrm{Mg}$ as the pyrolysis temperature increased from 450 to $600{ }^{\circ} \mathrm{C}$ using hickory wood as feedstock [21]. Thus, both the volatility of the nutrients and the influence of temperature on the composition and chemical structure of biochar can significantly affect the concentration of nutrients during the process [13].

\subsection{3. $\mathrm{pH}$ and Cation Exchange Capacity}

The generated biochars were generally alkaline $(\mathrm{pH}>7)$ and the $\mathrm{pH}$ of biochar significant increased from 7.48 to 11.62 when the pyrolysis temperature increased from 300 to $500{ }^{\circ} \mathrm{C}$, and then decreased to 10.60 in BC600 (Figure 2). This was probably due to the highest ash content in BC500. The $\mathrm{pH}$ values and ash content were positively correlated $\left(R^{2}=0.97\right)$, hence, the minerals, especially for the carbonates formation (such as $\mathrm{CaCO}_{3}$ and $\mathrm{MgCO}_{3}$ ) and inorganic alkalis (such as $\mathrm{K}$ and $\mathrm{Na}$ ), were probably the main cause of each biochars' inherent alkaline $\mathrm{pH}$ [28].

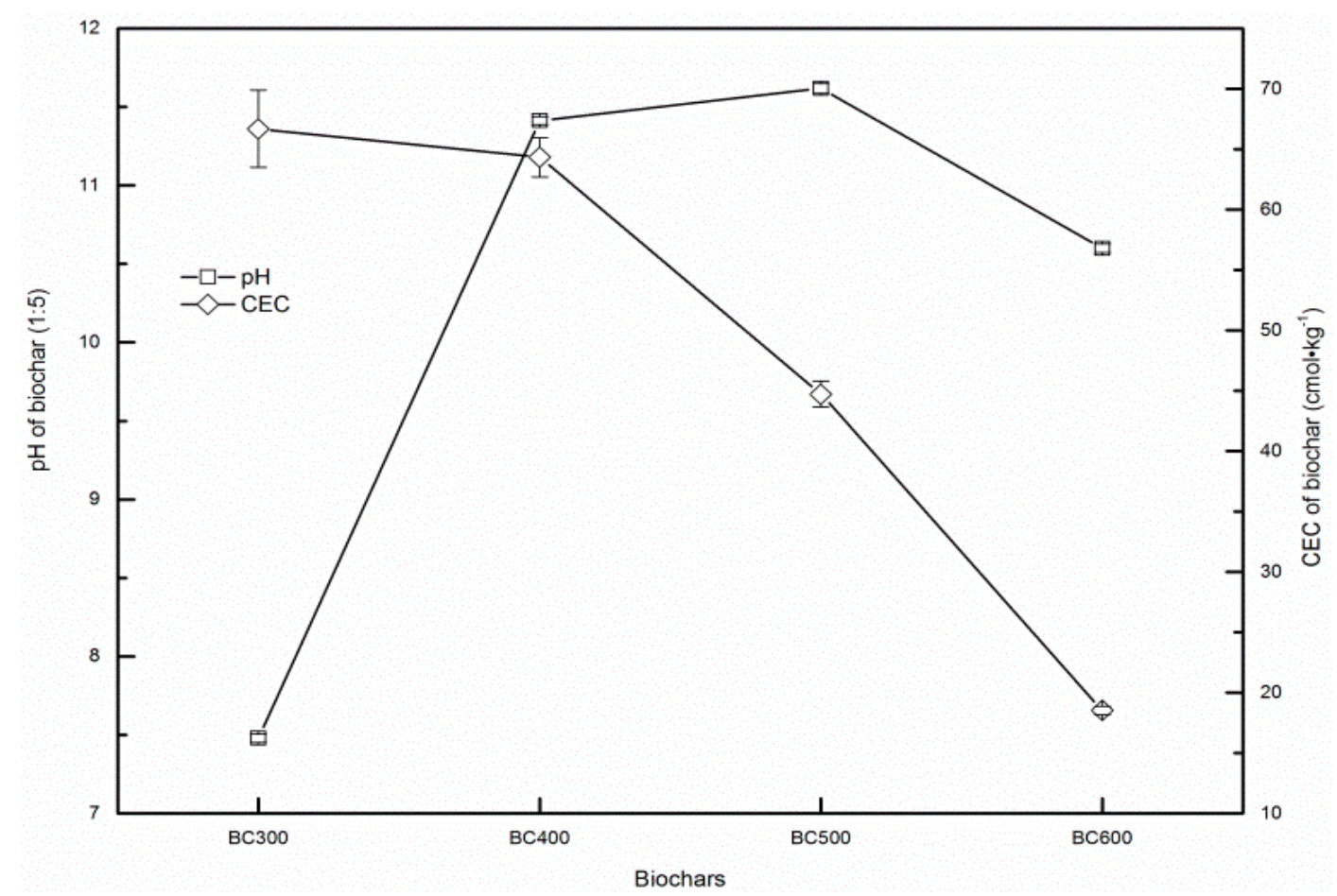

Figure 2. The $\mathrm{pH}$ and cation exchange capacity (CEC) of biochars produced at different temperatures. Individual points are averages $(n=3)$ and error bars are standard deviations.

CEC is an important property of biochar indicating the capacity of a biochar to adsorb cation nutrients [20]. In our study, the CEC for the generated biochars significantly decreased from 66.59 to $18.53 \mathrm{cmol} \cdot \mathrm{kg}^{-1}$ when the pyrolysis temperature increased from 300 to $600{ }^{\circ} \mathrm{C}$ (Figure 2), which was consistent with previous study [44]. The shift in CEC may due to the reduction of functional groups and oxidation of aromatic $C$ with temperature [34], which was well supported by the lower O/C ratio and our FTIR and Boehm titration results at higher temperature.

\subsection{Effect of Temperature on the Surface Properties of Biochars}

\subsubsection{Surface Morphology (Scanning Electron Microscopy Analysis)}

Figure 3 shows SEM micrographs $(\times 4000)$ of biochars produced at different temperatures. The image of BC300 showed that the biomass had softened, melted and fused into a mass of vesicles (Figure 3a) [45]. The vesicles were the result of volatile gasses released within the biomass. As temperatures increased, more 
volatile gasses released from the biomass, the vesicles on the surface of $\mathrm{BC} 400$ busted after cooling, thus the morphology of $\mathrm{BC} 400$ exhibited a number of pore structure (Figure 3b). For the BC500, portions of the skeletal structure appeared brittle because of the decomposition of more components (Figure 3c, ellipse). The fracture phenomenon also appeared within the pore structure for the $\mathrm{BC} 600$, the last temperature that samples were collected (Figure 3d, ellipse).
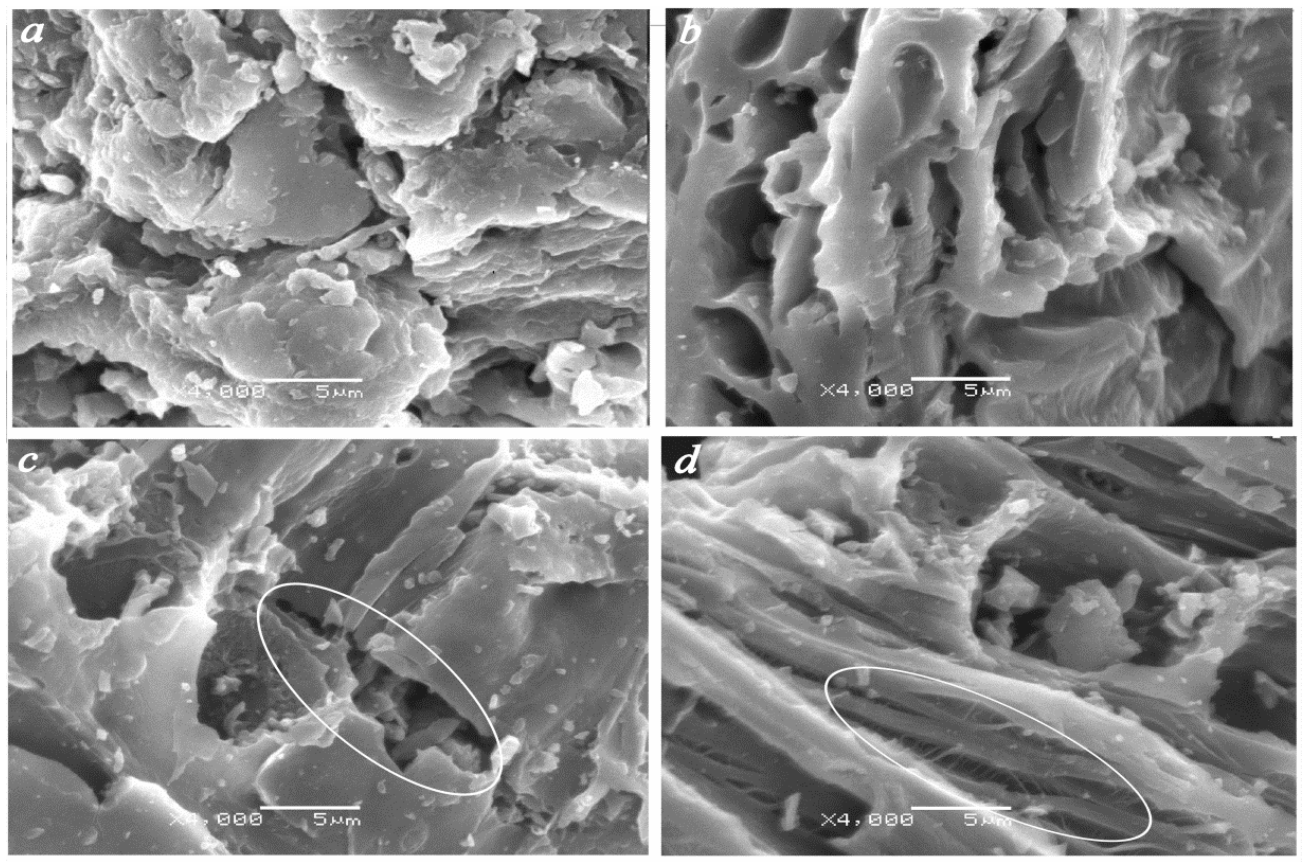

Figure 3. Scanning electron microscopy (SEM) micrographs (magnification $4000 \times$ ) of biochars samples pyrolyzed at: (a) $300{ }^{\circ} \mathrm{C}$; (b) $400{ }^{\circ} \mathrm{C}$; (c) $500{ }^{\circ} \mathrm{C}$; and (d) $600{ }^{\circ} \mathrm{C}$, respectively.

\subsubsection{Surface Area and Pore Volume}

The surface area and pore volumes produced at various pyrolysis temperatures were obtained by $\mathrm{N}_{2}$ adsorption and the results shown in Table 2. An increase in the pyrolysis temperature from 300 to $600{ }^{\circ} \mathrm{C}$ resulted in a significant increase in the $S_{\mathrm{BET}}$ from $2.39 \mathrm{~m}^{2} \cdot \mathrm{g}^{-1}$ to $108.59 \mathrm{~m}^{2} \cdot \mathrm{g}^{-1}$ and in the $V_{\mathrm{T}}$ from $2.56 \times 10^{-3} \mathrm{~cm}^{3} \cdot \mathrm{g}^{-1}$ to $58.54 \times 10^{-3} \mathrm{~cm}^{3} \cdot \mathrm{g}^{-1}$. In the same way, $S_{\text {mic }}$ and $V_{\text {mic }}$ significant increased from $0.10 \mathrm{~m}^{2} \cdot \mathrm{g}^{-1}$ and $0.13 \times 10^{-3} \mathrm{~cm}^{3} \cdot \mathrm{g}^{-1}$ at $300{ }^{\circ} \mathrm{C}$ to $84.44 \mathrm{~m}^{2} \cdot \mathrm{g}^{-1}$ and $37.87 \times 10^{-3}$ $\mathrm{cm}^{3} \cdot \mathrm{g}^{-1}$ at $600{ }^{\circ} \mathrm{C}$, respectively. This evolution is somewhat similar to that reported in the literature [15]. The increase in the surface area and pore volumes might be caused by the progressive degradation of the organic materials (hemicelluloses, cellulose and lignin) and the formation of vascular bundles or channel structures during pyrolysis during the process [46,47]. Hemicellulose has a high reactivity during thermal treatment at lower temperature (usually under $300{ }^{\circ} \mathrm{C}$ ).

Table 2. Surface area and pore volumes of biochars produced at different temperatures.

\begin{tabular}{ccccc}
\hline Sample & BC300 & BC400 & BC500 & BC600 \\
\hline$S_{\mathrm{BET}}\left(\mathrm{m}^{2} \cdot \mathrm{g}^{-1}\right)$ & $2.39 \pm 0.12 \mathrm{~d}$ & $7.00 \pm 0.25 \mathrm{c}$ & $37.24 \pm 0.80 \mathrm{~b}$ & $108.59 \pm 4.11 \mathrm{a}$ \\
$S_{\text {mic }}\left(\mathrm{m}^{2} \cdot \mathrm{g}^{-1}\right)$ & $0.10 \pm 0.01 \mathrm{~d}$ & $1.47 \pm 0.01 \mathrm{c}$ & $9.33 \pm 0.73 \mathrm{~b}$ & $84.44 \pm 6.76 \mathrm{a}$ \\
$V_{\mathrm{T}}\left(10^{-3} \cdot \mathrm{cm}^{3} \cdot \mathrm{g}^{-1}\right)$ & $2.56 \pm 0.25 \mathrm{~d}$ & $6.52 \pm 0.64 \mathrm{c}$ & $12.41 \pm 0.32 \mathrm{~b}$ & $58.54 \pm 3.44 \mathrm{a}$ \\
$V_{\text {mic }}\left(10^{-3} \cdot \mathrm{cm}^{3} \cdot \mathrm{g}^{-1}\right)$ & $0.13 \pm 0.01 \mathrm{~d}$ & $0.52 \pm 0.03 \mathrm{c}$ & $1.58 \pm 0.10 \mathrm{~b}$ & $37.87 \pm 0.91 \mathrm{a}$ \\
\hline
\end{tabular}

Note: Values in a row followed by the same letter are not significantly different at $p<0.05$ according to LSD test. All data were reported as means \pm standard deviation $(n=3) . S_{\mathrm{BET}}, S_{\text {mic }}, V_{\mathrm{T}}$ and $V_{\text {mic }}$ were the BET surface area, micropore surface area, total pore volume and micropore volume, respectively. 
The presence of vesicles at BC300 also indicated that volatile components were formed and released (Figure 3a). When the pyrolysis temperature increased from 300 to $400{ }^{\circ} \mathrm{C}$, the rupture of the hemicellulose along with other organic compounds generated more micropores within biochar (Figure 3b) [48], thus, an increase in the surface area and pore volumes was found in BC400. Meanwhile, some amorphous carbon structures were formed during this temperature range due to the degradation of cellulose. Several researchers suggested that the micropores may be formed by amorphous carbon structures [49]. The increase in the biochar porosity was found in BC500 due to the decomposition of lignin and the quick release of $\mathrm{H}_{2}$ and $\mathrm{CH}_{4}$ as the temperature increased up to $500{ }^{\circ} \mathrm{C}$ (Figure 3c). This result contributed to a sharp increase of the surface area and pore volumes (Table 2) [18]. Further increases in the temperature to $600^{\circ} \mathrm{C}$ resulting in a dramatic increase in $S_{\mathrm{BET}}$ and $V_{\mathrm{T}}$, especially for the $S_{\text {mic }}$ and $V_{\text {mic }}$. This was mostly contributed to the further degradation of lignin and the reaction of aromatic condensation [30], which increased the release of VM (Table 1) and created more pores (Figure 3d) [18]. The enhancement of the pore development at a higher temperature suggesting that the increase of $S_{\mathrm{BET}}$ and $V_{\mathrm{T}}$ mostly dependent on the increase of the $S_{\text {mic }}$ and $V_{\text {mic }}$.

\subsubsection{Fourier-Transform Infrared Analysis and Functional Groups}

The FTIR spectra of biochars produced at four pyrolysis temperatures are presented in Figure 4 and the descriptions for peak assignments are provided in Table 3. As the pyrolysis temperature increased, FTIR spectra of biochars revealed a decrease in the stretching of $\mathrm{O}-\mathrm{H}\left(3200-3500 \mathrm{~cm}^{-1}\right)$ and $\mathrm{C}-\mathrm{H}\left(2935 \mathrm{~cm}^{-1}\right)$ [13], this was attributed to the acceleration of dehydration reaction in biomass [30], which suggested a decrease in the polar functional groups with an increase in pyrolysis temperature [50]. In particular, biochars began to increase aromatic $C=C$ stretching $\left(1440 \mathrm{~cm}^{-1}\right)$ [29] and out-of-plane deformation by aromatic $\mathrm{C}-\mathrm{H}$ groups $\left(885 \mathrm{~cm}^{-1}\right)$ [51], while the symmetric $\mathrm{C}-\mathrm{O}$ stretching (1030-1110 $\mathrm{cm}^{-1}$ ) for the source material began to disappear with the increasing pyrolysis temperature [51].

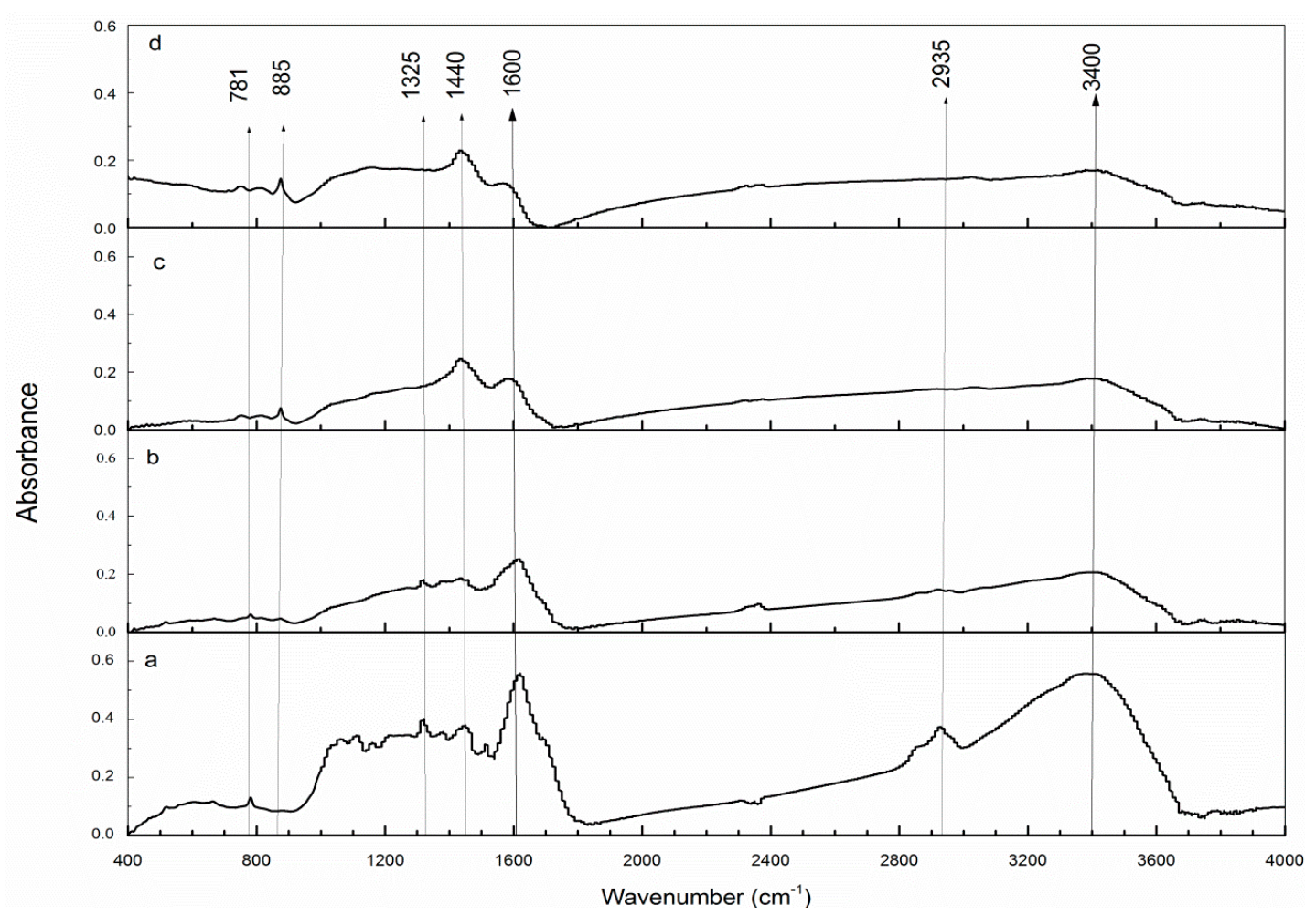

Figure 4. Fourier-transform infrared (FTIR) spectra peaks of biochars produced at: (a) $300{ }^{\circ} \mathrm{C}$; (b) $400{ }^{\circ} \mathrm{C}$; (c) $500{ }^{\circ} \mathrm{C}$; and (d) $600{ }^{\circ} \mathrm{C}$, respectively. 
Table 3. Functional groups observed in the Fourier-transform infrared (FTIR) spectra of biocahrs produced at different temperatures.

\begin{tabular}{cc}
\hline Wave Numbers $\left(\mathbf{c m}^{-\mathbf{1}}\right)$ & Characteristic Vibrations (Functionality) \\
$3500-3200$ & O-H stretching (water, hydrogen-bonded hydroxyl) [13] \\
2935 & C-H stretching (aliphatic CHx; 2935-asymmetric) [13] \\
1600 & Aromatic C=C and C=O stretching of conjugated ketones and quinones [52] \\
1440 & C=C stretching (lignin carbohydrate) [29] \\
1325 & O-H bending (phenols, phenolic; ligneous syringyl) [29] \\
$1100-1030$ & Symmetric C-O stretching (cellulose, hemicellulose, and lignin) [51] \\
885 & C-H bending (aromatic C-H out-of-plane deformation) [51] \\
781 & Pyridine (pyridine ring vibration and C-H deformation) [53] \\
\hline
\end{tabular}

This result is likely due to the degradation and depolymerization of cellulose, hemicelluloses and lignin [29]. Instead, intensities of $\mathrm{O}-\mathrm{H}\left(1325 \mathrm{~cm}^{-1}\right)$ stretching [29] and aromatic $\mathrm{C}=\mathrm{C}$ and $\mathrm{C}=\mathrm{O}$ stretching of conjugated ketones and quinones $\left(1600 \mathrm{~cm}^{-1}\right)$ [52] decreased with temperature which may suggest that phenolic and carboxylic compounds in lignin had been degraded [54]. There was also pyridine in biochars $\left(781 \mathrm{~cm}^{-1}\right)$ [53], which was one of the heterocyclic nitrogen compounds commonly observed during pyrolysis [55]. In general, the maximum loss was obtained in $-\mathrm{OH},-\mathrm{CH}_{2}$, and $\mathrm{C}-\mathrm{O}$ functional groups in biochars as a function of pyrolysis temperature, which was also apparent from their elemental composition (Table 1). Relatively low values of $\mathrm{O}, \mathrm{H}$, and $\mathrm{H} / \mathrm{C}$ in $\mathrm{BC} 600$ than those in $\mathrm{BC} 300$ revealed the significant elimination of polar functional groups $(-\mathrm{OH}$ and $\mathrm{C}-\mathrm{O})$.

Different spectra reflected changes in the surface functional groups of biochars produced at different temperatures. A Boehm titration method was used to quantify the surface functional groups of biochars produced at different temperatures. The results showed that when the pyrolysis temperature increased from 300 to $600{ }^{\circ} \mathrm{C}$ the concentration of total acidic functional groups, surface carboxylic functional groups, surface phenolic functional groups and surface lactonic functional groups decreased from 1.16 to $0.44 \mathrm{mmol} \cdot \mathrm{g}^{-1}, 0.49$ to $0.23 \mathrm{mmol} \cdot \mathrm{g}^{-1}, 0.33$ to $0.09 \mathrm{mmol} \cdot \mathrm{g}^{-1}$ and 0.34 to $0.13 \mathrm{mmol} \cdot \mathrm{g}^{-1}$, respectively (Figure 5). This result was in agreement with the findings in previous studies [56,57]. During the pyrolysis process, organic materials were converted to water and carbonaceous gas, thus, the higher temperature caused an increased in the quantity of volatile compounds resulting in a decrease in the content of acidic groups [18], which was well supported by our FTIR results. It was interesting that the total acidic and carboxylic functional groups significant decreased with increasing temperatures $(p<0.05)$, whereas the temperature trend for phenolic and lactonic functional groups content were less apparent (Figure 5). This was probably due to the fact carboxylic acids represented $48.63 \%$ of total acidic functional groups, on average, and were 1.5-2.5 times more abundant than phenolic or lactonic functional groups. This result is similar to the one reported in the literature [15]. While, the total basic functional groups significant increased from 0.11 to $0.32 \mathrm{mmol} \cdot \mathrm{g}^{-1}$ when the pyrolysis temperature increased from 300 to $500{ }^{\circ} \mathrm{C}$ and then decreased to $0.22 \mathrm{mmol} \cdot \mathrm{g}^{-1}$ at $600{ }^{\circ} \mathrm{C}$. The strong direct linear correlation between ash fraction and basic groups $\left(R^{2}=0.66\right)$ suggest that the basic functional groups are mainly associated with the ash fraction [15], which also implied the highest content of basic groups in BC500 (Figure 5 and Table 1). 


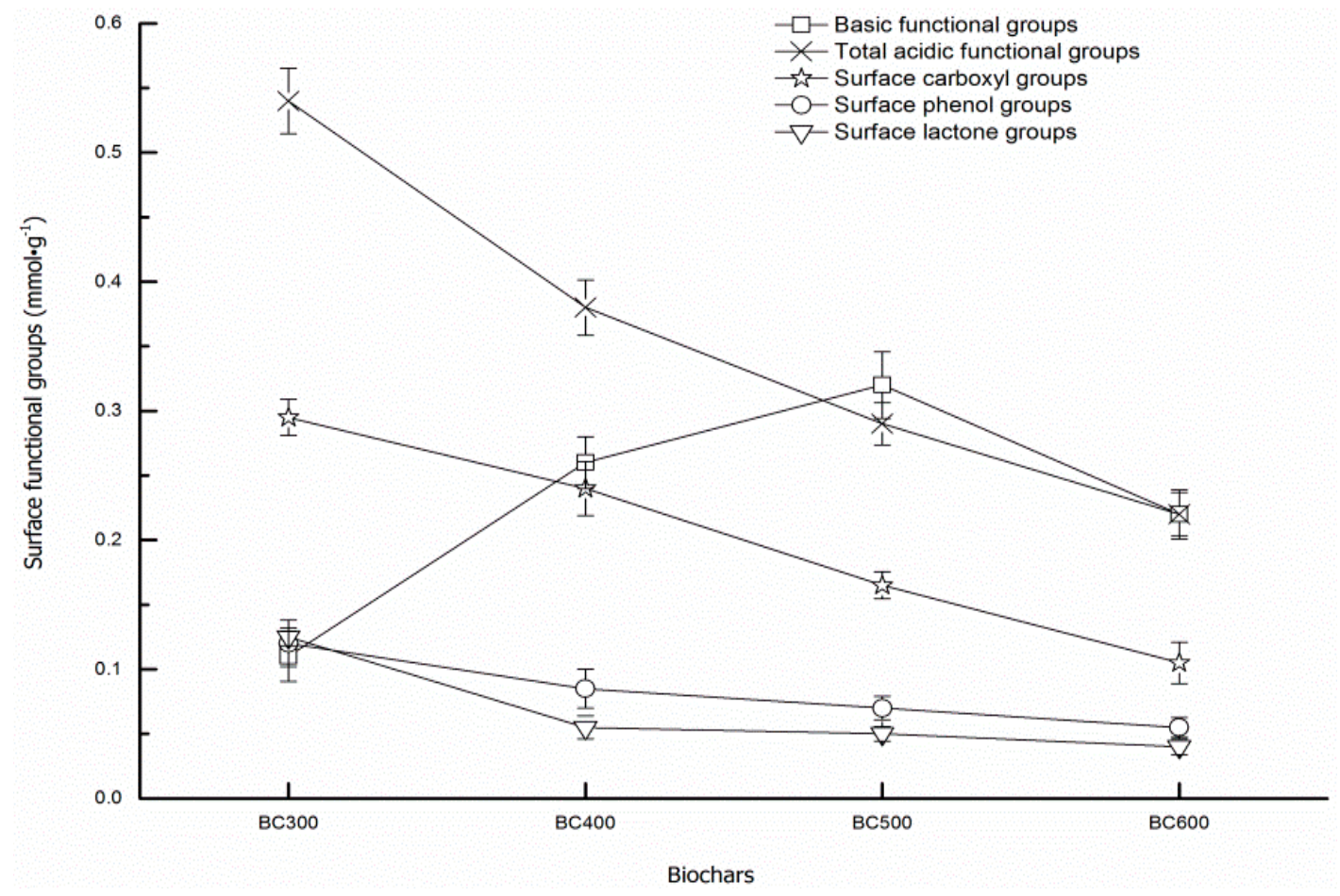

Figure 5. Variation in surface functional groups as a function of pyrolysis temperature. Individual points are averages $(n=3)$ and error bars are standard deviations.

\subsection{Effect of Temperature on the Thermal Stability of Biochars}

Representative thermogravimetric (TG) analysis and differential thermogravimetry (DTG) curves for both biochars are presented in Figure 6. During the process, two stages of weight losses were observed (Figure 6a), which was also implied by the DTG curves (Figure 6b). The mass loss occurred slowly under $200{ }^{\circ} \mathrm{C}$ and varied from $0.77 \%$ to $2.86 \%$ (Figure 6a; maximum at around $80{ }^{\circ} \mathrm{C}$, Figure $6 \mathrm{~b}$ ) (under $200{ }^{\circ} \mathrm{C}$ ), suggesting that this reduction in mass loss commonly associated with the loss of the initial moisture of the sample [58]. Above that, the main mass losses started at around $315^{\circ} \mathrm{C}$, $388^{\circ} \mathrm{C}, 499^{\circ} \mathrm{C}$ and $517^{\circ} \mathrm{C}$ for BC300, BC400, BC500 and BC600, respectively. Meanwhile, a sharp weight decrease took place between $313^{\circ} \mathrm{C}$ and $500{ }^{\circ} \mathrm{C}, 388^{\circ} \mathrm{C}$ and $644^{\circ} \mathrm{C}, 499^{\circ} \mathrm{C}$ and $738^{\circ} \mathrm{C}, 517{ }^{\circ} \mathrm{C}$ and $753{ }^{\circ} \mathrm{C}$ (Figure 6a) in the BC300, BC400, BC500 and BC600, respectively. This was probably due to the fact the generated biochars had undergone a previous heat treatment before the thermal analysis, thus, the tested biochar samples were thermally stable below the temperature which they were produced [59]. For each of the tested biochar, only one peak was found during the temperature range between the temperature they were produced and $1000{ }^{\circ} \mathrm{C}$ on the DTG curves (Figure 6b). It is known that secondary pyrolysis reactions could be easily detected and observed if the temperature exceeding the biochars' primary decomposition temperature [58]. Thus, the weight loss over a wider temperature range could be attributed to the degradation and decomposition of organic materials [21]. The maximum weight loss occurred at around $352{ }^{\circ} \mathrm{C}, 388^{\circ} \mathrm{C}, 658^{\circ} \mathrm{C}$ and $674{ }^{\circ} \mathrm{C}$ for $\mathrm{BC} 300, \mathrm{BC} 400$, $\mathrm{BC} 500$ and BC600 (Figure 6b), respectively, suggesting that the higher the pyrolysis temperature was, the better thermal stability the biochar showed, which is consistent with the literature [60]. The lower temperature derived biochars were less thermally stable than the higher temperature derived biochars, probably because they were not fully carbonized [21]. Above $600-700{ }^{\circ} \mathrm{C}$, decomposition for all the biochars finished, and the curves became stable. It was interesting that the total weight losses resulting from thermal degradation were $52.19 \%, 33.32 \%, 23.80 \%$ and $27.27 \%$ for BC300, BC400, BC500 and BC600, respectively. This was probably because BC500 had highest ash content. 
(a)

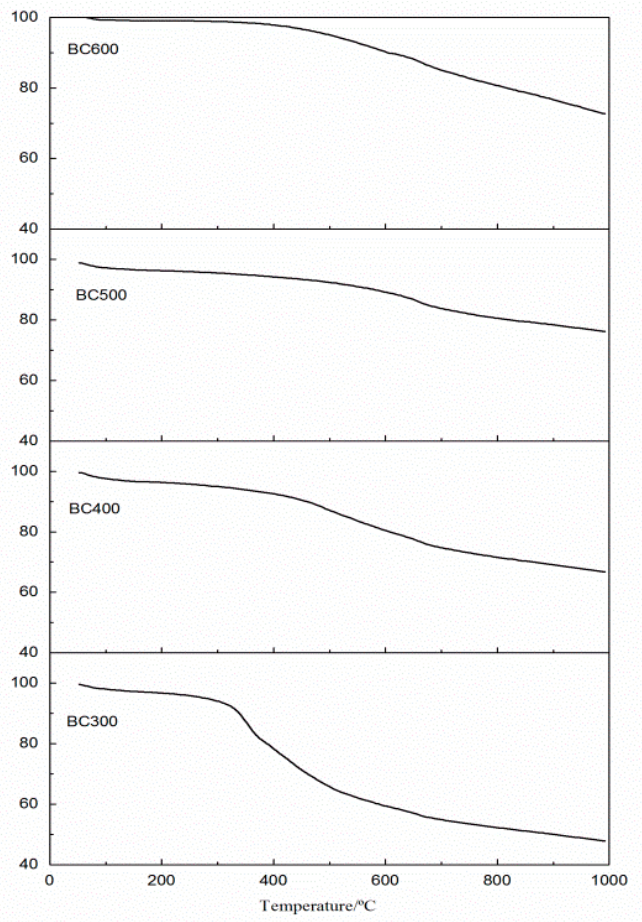

(b)

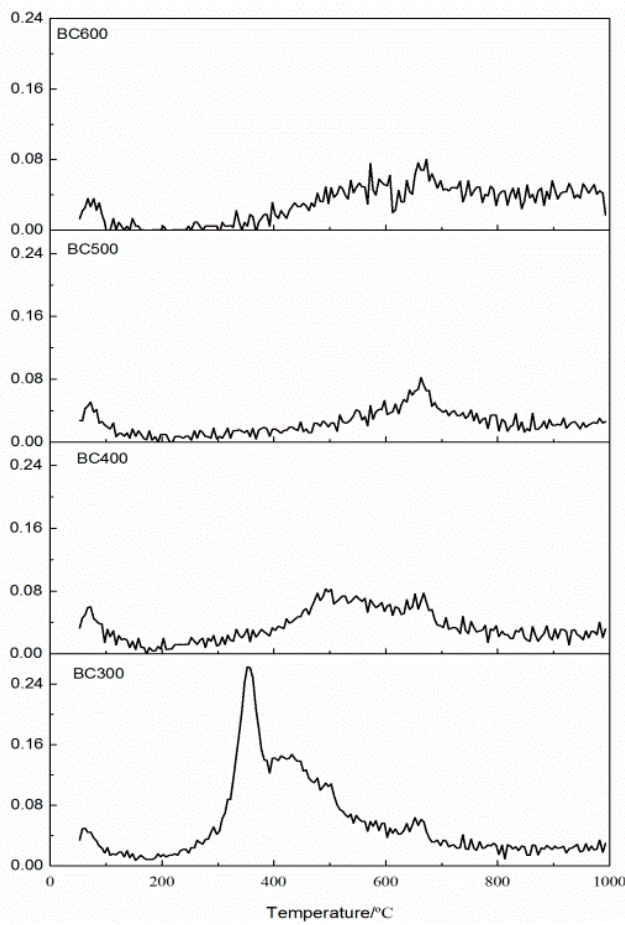

Figure 6. Thermogravimetric (TG). (a) Differential thermogravimetry (DTG); and (b) curves of biochars produced at $300{ }^{\circ} \mathrm{C}, 400{ }^{\circ} \mathrm{C}, 500{ }^{\circ} \mathrm{C}$ and $600{ }^{\circ} \mathrm{C}$, respectively.

\subsection{Implications for Environmental and Agronomic Management}

Biochar is a carbon-rich product and its addition to soil has been proposed as an effective method for $C$ sequestration [61]. However, the ultimate $C$ sequestration efficiency of biochar mainly depend on its stability, which is mainly effect by the production conditions including pyrolysis temperature [37]. Lehmann et al. suggested that a biochar can be used as an effective $C$ sequestration agents in case its $\mathrm{O}: \mathrm{C}$ and $\mathrm{H}: \mathrm{C}$ ratios less than 0.4 and 0.6, respectively [62]. Based on the results, ATB biochars produced at higher temperatures $\left(>400^{\circ} \mathrm{C}\right)$ with $\mathrm{H} / \mathrm{C}$ of $0.46-0.41$ and $\mathrm{O} / \mathrm{C}$ of $0.10-0.06$, may exhibit a high $\mathrm{C}$ sequestration potential. Thus, biochars produced at higher temperatures $\left(>400^{\circ} \mathrm{C}\right)$ could be more resistant to mineralization than those pyrolyzed at lower temperature $\left(\leq 400{ }^{\circ} \mathrm{C}\right)$, thus representing an efficient technique for mitigating greenhouse gas emissions into the environment. In addition, biochars produced at higher temperatures may prove beneficial for use as fertilizer due to their concentrations of minerals like $\mathrm{K}$ and $\mathrm{Na}$. However, our results also show that higher pyrolysis temperatures also have the potential of accumulating heavy metals, which can cause soil pollution. Biochars from pyrolysis processes are usually alkaline in nature, especially for the biochars produced at higher pyrolysis temperatures. Therefore, the application of these higher temperature biochars can be useful to increase the $\mathrm{pH}$ of acidic soils, which are in risk of aluminum toxicity [63]. In contrast, the application of these higher temperature biochars to arid soils may be critical of concern due to their high salinity and alkalinity. While, compared with the higher temperature biochars, ATB biochars produced at the lower pyrolysis temperature $\left(\leq 400^{\circ} \mathrm{C}\right)$ have more organic functional groups on their surface, high cation exchange capacity, lower $\mathrm{pH}$ values as well as less aromatic content. Thus, the ATB biochars produced at the lower pyrolysis temperature $\left(\leq 400^{\circ} \mathrm{C}\right)$ may be used to enhance the soil nutrient exchange sites as well as soil cation exchange capacity when they are applied to arid soils.

\section{Conclusions}

The structural and physicochemical properties of biochar derived from ATBs change with pyrolysis temperature. The results show that yield, VM, CEC and $\mathrm{H}$ and $\mathrm{O}$ were decreased with 
increasing pyrolysis temperature, whereas total C, fixed C, BET surface area, pore volumes and inorganic minerals (except for $\mathrm{Cu}$ and $\mathrm{Mn}$ ) concentrations increased with the increase in pyrolysis temperature. The $\mathrm{pH}$ and ash content increased as temperature increased up to $500{ }^{\circ} \mathrm{C}$ and decreased at higher temperature. The increasing temperature also decreased the acidic functional groups, especially for the carboxylic functional groups. While, reverse trend was found for the basic functional groups of biochars. In general, higher temperatures $\left(>400^{\circ} \mathrm{C}\right)$ biochars possessing predominately aromatic carbon structures and highly thermal stability, which can be useful to help mitigate climate change, while, lower temperature $\left(\leq 400{ }^{\circ} \mathrm{C}\right)$ biochars having more functional groups as well as relatively low $\mathrm{pH}$ values may be more suitable for improving the fertility of high $\mathrm{pH}$ soils in arid regions. Consequently different ATB biochars can be produced by changing the pyrolysis temperature in order to better meet specific application needs.

Acknowledgments: This research was supported by the National Key Technology R\&D Program of the Ministry of Science and Technology, China (2012BAD14B11), and the Special Fund for Agro-Scientific Research in the Public Interest of the Ministry of Agriculture, China (201503116).

Author Contributions: All authors conceived, designed and performed the experiment. Xu-Dong Wang provided technical and theoretical support; Na Ta contributed to the analysis of experimental results; Shi-Xiang Zhao wrote the paper and all authors read and approved the final version.

Conflicts of Interest: The authors declare no conflicts of interest.

$\begin{array}{ll}\text { Abbreviations } \\ \mathrm{C} & \text { Carbon } \\ \mathrm{N} & \text { Nitrogen } \\ \mathrm{H} & \text { Hydrogen } \\ \mathrm{O} & \text { Oxygen } \\ \mathrm{CEC} & \text { Cation exchange capacity } \\ \mathrm{ATB} & \text { Apple tree branch } \\ \mathrm{VM} & \text { Volatile matter } \\ \mathrm{SEM} & \text { Scanning electron microscopy } \\ \text { BET } & \text { Brunauer-Emmett-Teller } \\ S_{\mathrm{BET}} & \text { BET surface area } \\ S_{\text {mic }} & \text { Micropore surface area; } \\ V_{\mathrm{T}} & \text { Total pore volume } \\ V_{\text {mic }} & \text { Micropore volume } \\ \text { FTIR } & \text { Fourier-transform infrared } \\ \text { TG } & \text { Thermogravimetric } \\ \text { DTG } & \text { Differential thermogravime }\end{array}$

\section{References}

1. Zhao, R.; Coles, N.; Wu, J. Carbon mineralization following additions of fresh and aged biochar to an infertile soil. Catena 2015, 125, 183-189. [CrossRef]

2. Purakayastha, T.J.; Das, K.C.; Gaskin, J.; Harris, K.; Smith, J.L.; Kumari, S. Effect of pyrolysis temperatures on stability and priming effects of C3 and C4 biochars applied to two different soils. Soil Tillage Res. 2016, 155, 107-115. [CrossRef]

3. Smith, J.L.; Collins, H.P.; Bailey, V.L. The effect of young biochar on soil respiration. Soil Biol. Biochem. 2010, 42, 2345-2347. [CrossRef]

4. Abujabhah, I.S.; Bound, S.A.; Doyle, R.; Bowman, J.P. Effects of biochar and compost amendments on soil physico-chemical properties and the total community within a temperate agricultural soil. Appl. Soil Ecol. 2016, 98, 243-253. [CrossRef]

5. Partey, S.T.; Saito, K.; Preziosi, R.F.; Robson, G.D. Biochar use in a legume-rice rotation system: Effects on soil fertility and crop performance. Arch. Agron. Soil Sci. 2015, 62, 199-215. [CrossRef] 
6. Zhou, J.; Chen, H.; Huang, W.; Arocena, J.M.; Ge, S. Sorption of Atrazine, $17 \alpha$-Estradiol, and Phenanthrene on Wheat Straw and Peanut Shell Biochars. Water Air Soil Pollut. 2016, 227, 7. [CrossRef]

7. Venegas, A.; Rigol, A.; Vidal, M. Changes in heavy metal extractability from contaminated soils remediated with organic waste or biochar. Geoderma 2016, 279, 132-140. [CrossRef]

8. Angin, D.; Sensöz, S. Effect of pyrolysis temperature on chemical and surface properties of biochar of rapeseed (Brassica napus L.). Int. J. Phytoremed. 2014, 16, 684-693. [CrossRef] [PubMed]

9. Roberts, D.A.; De, N.R. The effects of feedstock pre-treatment and pyrolysis temperature on the production of biochar from the green seaweed Ulva. J. Environ. Manag. 2016, 169, 253-260. [CrossRef] [PubMed]

10. Yang, X.; Wang, H.; Strong, P.; Xu, S.; Liu, S.; Lu, K.; Sheng, K.; Guo, J.; Che, L.; He, L. Thermal Properties of Biochars Derived from Waste Biomass Generated by Agricultural and Forestry Sectors. Energies 2017, 10, 469. [CrossRef]

11. Jouiad, M.; Al-Nofeli, N.; Khalifa, N.; Benyettou, F.; Yousef, L.F. Characteristics of slow pyrolysis biochars produced from rhodes grass and fronds of edible date palm. J. Anal. Appl. Pyrolysis 2015, 111, 183-190. [CrossRef]

12. Zhang, J.; Liu, J.; Liu, R. Effects of pyrolysis temperature and heating time on biochar obtained from the pyrolysis of straw and lignosulfonate. Bioresour. Technol. 2015, 176, 288-291. [CrossRef] [PubMed]

13. Claoston, N.; Samsuri, A.W.; Ahmad Husni, M.H.; Mohd Amran, M.S. Effects of pyrolysis temperature on the physicochemical properties of empty fruit bunch and rice husk biochars. Waste Manag. Res. 2014, 32, 331-339. [CrossRef] [PubMed]

14. Bouraoui, Z.; Jeguirim, M.; Guizani, C.; Limousy, L.; Dupont, C.; Gadiou, R. Thermogravimetric study on the influence of structural, textural and chemical properties of biomass chars on $\mathrm{CO}_{2}$ gasification reactivity. Energy 2015, 88, 703-710. [CrossRef]

15. Suliman, W.; Harsh, J.B.; Abu-Lail, N.I.; Fortuna, A.M.; Dallmeyer, I.; Garcia-Perez, M. Influence of feedstock source and pyrolysis temperature on biochar bulk and surface properties. Biomass Bioenergy 2016, 84, 37-48. [CrossRef]

16. $\mathrm{Xu}, \mathrm{Y}$;; Chen, B. Investigation of thermodynamic parameters in the pyrolysis conversion of biomass and manure to biochars using thermogravimetric analysis. Bioresour. Technol. 2013, 146, 485-493. [CrossRef] [PubMed]

17. Guizani, C.; Jeguirim, M.; Valin, S.; Limousy, L.; Salvador, S. Biomass Chars: The Effects of Pyrolysis Conditions on Their Morphology, Structure, Chemical Properties and Reactivity. Energies 2017, 10, 796. [CrossRef]

18. Shaaban, A.; Se, S.-M.; Dimin, M.F.; Juoi, J.M.; Mohd Husin, M.H.; Mitan, N.M.M. Influence of heating temperature and holding time on biochars derived from rubber wood sawdust via slow pyrolysis. J. Anal. Appl. Pyrolysis 2014, 107, 31-39. [CrossRef]

19. Liang, C.F.; Gasco, G.; Fu, S.L.; Mendez, A.; Paz-Ferreiro, J. Biochar from pruning residues as a soil amendment: Effects of pyrolysis temperature and particle size. Soil Tillage Res. 2016, 164, 3-10. [CrossRef]

20. Tag, A.T.; Duman, G.; Ucar, S.; Yanik, J. Effects of feedstock type and pyrolysis temperature on potential applications of biochar. J. Anal. Appl. Pyrolysis 2016, 120, 200-206. [CrossRef]

21. Sun, Y.N.; Gao, B.; Yao, Y.; Fang, J.N.; Zhang, M.; Zhou, Y.M.; Chen, H.; Yang, L.Y. Effects of feedstock type, production method, and pyrolysis temperature on biochar and hydrochar properties. Chem. Eng. J. 2014, 240, 574-578. [CrossRef]

22. Brassard, P.; Godbout, S.; Raghavan, V.; Palacios, J.H.; Grenier, M.; Dan, Z. The Production of Engineered Biochars in a Vertical Auger Pyrolysis Reactor for Carbon Sequestration. Energies 2017, 10, 288. [CrossRef]

23. Colantoni, A.; Zambon, I.; Colosimo, F.; Monarca, D.; Cecchini, M.; Gallucci, F.; Proto, A.R.; Lord, R. An Innovative Agro-Forestry Supply Chain for Residual Biomass: Physicochemical Characterisation of Biochar from Olive and Hazelnut Pellets. Energies 2016, 9, 526. [CrossRef]

24. Fang, K.; Li, H.; Wang, Z.; Du, Y.; Wang, J. Comparative analysis on spatial variability of soil moisture under different land use types in orchard. Sci. Hortic. 2016, 207, 65-72. [CrossRef]

25. Bai, S.H.; Reverchon, F.; Xu, C.-Y.; Xu, Z.; Blumfield, T.J.; Zhao, H.; Van Zwieten, L.; Wallace, H.M. Wood biochar increases nitrogen retention in field settings mainly through abiotic processes. Soil Biol. Biochem. 2015, 90, 232-240. [CrossRef] 
26. Eyles, A.; Bound, S.A.; Oliver, G.; Corkrey, R.; Hardie, M.; Green, S.; Close, D.C. Impact of biochar amendment on the growth, physiology and fruit of a young commercial apple orchard. Trees 2015, 29, 1817-1826. [CrossRef]

27. ASTM International. D5142, Standard Test Methods for Proximate Analysis of the Analysis Sample of Coal and Coke by Instrumental Procedures. In American Society for Testing and Materials; ASTM International: West Conshohocken, PA, USA, 2009.

28. Yuan, J.H.; Xu, R.K.; Zhang, H. The forms of alkalis in the biochar produced from crop residues at different temperatures. Bioresour. Technol. 2011, 102, 3488-3497. [CrossRef] [PubMed]

29. Cantrell, K.B.; Hunt, P.G.; Uchimiya, M.; Novak, J.M.; Ro, K.S. Impact of pyrolysis temperature and manure source on physicochemical characteristics of biochar. Bioresour. Technol. 2012, 107, 419-428. [CrossRef] [PubMed]

30. Chen, Y.; Yang, H.; Wang, X.; Zhang, S.; Chen, H. Biomass-based pyrolytic polygeneration system on cotton stalk pyrolysis: Influence of temperature. Bioresour. Technol. 2012, 107, 411-418. [CrossRef] [PubMed]

31. Boehm, H.P. Some aspects of the surface chemistry of carbon blacks and other carbons. Carbon 1994, 32, 759-769. [CrossRef]

32. Intani, K.; Latif, S.; Kabir, A.K.M.R.; Müller, J. Effect of self-purging pyrolysis on yield of biochar from maize cobs, husks and leaves. Bioresour. Technol. 2016, 218, 541-551. [CrossRef] [PubMed]

33. Ronsse, F.; Hecke, S.V.; Dickinson, D.; Prins, W. Production and characterization of slow pyrolysis biochar: Influence of feedstock type and pyrolysis conditions. Glob. Chang. Biol. Bioenergy 2013, 5, 104-115. [CrossRef]

34. Zornoza, R.; Moreno-Barriga, F.; Acosta, J.A.; Muñoz, M.A.; Faz, A. Stability, nutrient availability and hydrophobicity of biochars derived from manure, crop residues, and municipal solid waste for their use as soil amendments. Chemosphere 2016, 144, 122-130. [CrossRef] [PubMed]

35. Chen, T.; Zhang, Y.; Wang, H.; Lu, W.; Zhou, Z.; Zhang, Y.; Ren, L. Influence of pyrolysis temperature on characteristics and heavy metal adsorptive performance of biochar derived from municipal sewage sludge. Bioresour. Technol. 2014, 164, 47-54. [CrossRef] [PubMed]

36. Wang, X.; Zhou, W.; Liang, G.; Song, D.; Zhang, X. Characteristics of maize biochar with different pyrolysis temperatures and its effects on organic carbon, nitrogen and enzymatic activities after addition to fluvo-aquic soil. Sci. Total Environ. 2015, 538, 137-144. [CrossRef] [PubMed]

37. Usman, A.R.A.; Abduljabbar, A.; Vithanage, M.; Ok, Y.S.; Ahmad, M.; Ahmad, M.; Elfaki, J.; Abdulazeem, S.S.; Al-Wabel, M.I. Biochar production from date palm waste: Charring temperature induced changes in composition and surface chemistry. J. Anal. Appl. Pyrolysis 2015, 115, 392-400. [CrossRef]

38. Zhang, J.N.; Lu, F.; Luo, C.H.; Shao, L.M.; He, P.J. Humification characterization of biochar and its potential as a composting amendment. J. Environ. Sci. 2014, 26, 390-397. [CrossRef]

39. Li, X.; Shen, Q.; Zhang, D.; Mei, X.; Ran, W.; Xu, Y.; Yu, G. Functional Groups Determine Biochar Properties ( $\mathrm{pH}$ and EC) as Studied by Two-Dimensional ${ }^{13} \mathrm{C}$ NMR Correlation Spectroscopy. PLoS ONE 2013, 8, e65949. [CrossRef] [PubMed]

40. Tan, X.; Liu, Y.; Zeng, G.; Wang, X.; Hu, X.; Gu, Y.; Yang, Z. Application of biochar for the removal of pollutants from aqueous solutions. Chemosphere 2015, 125, 70-85. [CrossRef] [PubMed]

41. Keiluweit, M.; Nico, P.S.; Johnson, M.G.; Kleber, M. Dynamic molecular structure of plant biomass-derived black carbon (biochar). Environ. Sci. Technol. 2010, 44, 1247-1253. [CrossRef] [PubMed]

42. Chen, X.; Chen, G.; Chen, L.; Chen, Y.; Lehmann, J.; McBride, M.B.; Hay, A.G. Adsorption of copper and zinc by biochars produced from pyrolysis of hardwood and corn straw in aqueous solution. Bioresour. Technol. 2011, 102, 8877-8884. [CrossRef] [PubMed]

43. Pituello, C.; Francioso, O.; Simonetti, G.; Pisi, A.; Torreggiani, A.; Berti, A.; Morari, F. Characterization of chemical-physical, structural and morphological properties of biochars from biowastes produced at different temperatures. J. Soils Sediments 2015, 15, 792-804. [CrossRef]

44. Phuong, H.T.; Uddin, M.A.; Kato, Y. Characterization of Biochar from Pyrolysis of Rice Husk and Rice Straw. J. Biobased Mater. Bioenergy 2015, 9, 439-446. [CrossRef]

45. Sharma, R.K.; Wooten, J.B.; Baliga, V.L.; Lin, X.; Geoffrey Chan, W.; Hajaligol, M.R. Characterization of chars from pyrolysis of lignin. Fuel 2004, 83, 1469-1482. [CrossRef]

46. Kim, W.K.; Shim, T.; Kim, Y.S.; Hyun, S.; Ryu, C.; Park, Y.K.; Jung, J. Characterization of cadmium removal from aqueous solution by biochar produced from a giant Miscanthus at different pyrolytic temperatures. Bioresour. Technol. 2013, 138, 266-270. [CrossRef] [PubMed] 
47. Li, M.; Liu, Q.; Guo, L.; Zhang, Y.; Lou, Z.; Wang, Y.; Qian, G. Cu(II) removal from aqueous solution by Spartina alterniflora derived biochar. Bioresour. Technol. 2013, 141, 83-88. [CrossRef] [PubMed]

48. Jeong, C.Y.; Dodla, S.K.; Wang, J.J. Fundamental and molecular composition characteristics of biochars produced from sugarcane and rice crop residues and by-products. Chemosphere 2016, 142, 4-13. [CrossRef] [PubMed]

49. Vamvuka, D.; Sfakiotakis, S. Effects of heating rate and water leaching of perennial energy crops on pyrolysis characteristics and kinetics. Renew. Energy 2011, 36, 2433-2439. [CrossRef]

50. Zhou, L.; Liu, Y.; Liu, S.; Yin, Y.; Zeng, G.; Tan, X.; Hu, X.; Hu, X.; Jiang, L.; Ding, Y.; et al. Investigation of the adsorption-reduction mechanisms of hexavalent chromium by ramie biochars of different pyrolytic temperatures. Bioresour. Technol. 2016, 218, 351-359. [CrossRef] [PubMed]

51. Ahmad, M.; Lee, S.S.; Dou, X.; Mohan, D.; Sung, J.K.; Yang, J.E.; Ok, Y.S. Effects of pyrolysis temperature on soybean stover- and peanut shell-derived biochar properties and TCE adsorption in water. Bioresour. Technol. 2012, 118, 536-544. [CrossRef] [PubMed]

52. Uchimiya, M.; Wartelle, L.H.; Klasson, K.T.; Fortier, C.A.; Lima, I.M. Influence of pyrolysis temperature on biochar property and function as a heavy metal sorbent in soil. J. Agric. Food Chem. 2011, 59, 2501-2510. [CrossRef] [PubMed]

53. Das, D.D.; Schnitzer, M.I.; Monreal, C.M.; Mayer, P. Chemical composition of acid-base fractions separated from biooil derived by fast pyrolysis of chicken manure. Bioresour. Technol. 2009, 100, 6524-6532. [CrossRef] [PubMed]

54. Souza, B.S.; Moreira, A.P.D.; Teixeira, A.M.R.F. TG-FTIR coupling to monitor the pyrolysis products from agricultural residues. J. Therm. Anal. Calorim. 2009, 97, 637-642. [CrossRef]

55. Kazi, Z.H.; Schnitzer, M.I.; Monreal, C.M.; Mayer, P. Separation and identification of heterocyclic nitrogen compounds in biooil derived by fast pyrolysis of chicken manure. J. Environ. Sci. Health Part B Pestic. Food Contam. Agric. Wastes 2011, 46, 51-61. [CrossRef] [PubMed]

56. Mukherjee, A.; Zimmerman, A.R.; Harris, W. Surface chemistry variations among a series of laboratory-produced biochars. Geoderma 2011, 163, 247-255. [CrossRef]

57. Doydora, S.A.; Cabrera, M.L.; Das, K.C.; Gaskin, J.W.; Sonon, L.S.; Miller, W.P. Release of Nitrogen and Phosphorus from Poultry Litter Amended with Acidified Biochar. Int. J. Environ. Res. Publ. Health 2011, 8 , 1491-1502. [CrossRef] [PubMed]

58. Santos, L.B.; Striebeck, M.V.; Crespi, M.S.; Ribeiro, C.A.; De Julio, M. Characterization of biochar of pine pellet. J. Therm. Anal. Calorim. 2015, 122, 21-32. [CrossRef]

59. Wu, H.; Che, X.; Ding, Z.; Hu, X.; Creamer, A.E.; Chen, H.; Gao, B. Release of soluble elements from biochars derived from various biomass feedstocks. Environ. Sci. Pollut. Res. 2016, 23, 1905-1915. [CrossRef] [PubMed]

60. Bruun, E.W.; Hauggaard-Nielsen, H.; Ibrahim, N.; Egsgaard, H.; Ambus, P.; Jensen, P.A.; Dam-Johansen, K. Influence of fast pyrolysis temperature on biochar labile fraction and short-term carbon loss in a loamy soil. Biomass Bioenergy 2011, 35, 1182-1189. [CrossRef]

61. Lehmann, J. A handful of carbon. Nature 2007, 447, 143-144. [CrossRef] [PubMed]

62. Ippolito, J.A.; Laird, D.A.; Busscher, W.J. Environmental benefits of biochar. J. Environ. Q. 2012, 41, 967-972. [CrossRef] [PubMed]

63. Wan, Q.; Yuan, J.H.; Xu, R.K.; Li, X.H. Pyrolysis temperature influences ameliorating effects of biochars on acidic soil. Environ. Sci. Pollut. Res. Int. 2014, 21, 2486-2495. [CrossRef] [PubMed]

(C) 2017 by the authors. Licensee MDPI, Basel, Switzerland. This article is an open access article distributed under the terms and conditions of the Creative Commons Attribution (CC BY) license (http:/ / creativecommons.org/licenses/by/4.0/). 